\title{
HAEMATOLOGICAL AND BIOCHEMICAL INDICES OF BLOOD IN WELS (Silurus glanis L.) FROM INTENSIVE AQUACULTURE
}

\author{
J. JIRÁSEK ${ }^{\prime \prime}$, J. MAREŚ ${ }^{\prime \prime}$, M. PALIKOVÄ ${ }^{2 \prime}$ \\ "Mendel University of Agriculture and Forestry. Brno. Czech Republic \\ 2) University of Veterinary and Pharmaceutical Sciences. Brno. Czech Republic
}

Received Julv 24, 1998

Accepted September 21, 1998

\begin{abstract}
Jirásek, J., J. Mareš, M. Palíková: Haematological and Biochemical Indices of Blood in Wels (Silurus Glanis L.) from Intensive Aquaculture. Acta vet. Brno 1998, 67: 227-233.

The objective of the present study was to determine the values of basic blood indicators and of biochemical plasma indicators of wels (Silurus glanis L.) intensively bred in warmed power station water without natural feeds. The study included 8 feeding experiments using 4 imported (ALMA, BioMar) and 4 domestic pelleted feeds with different protein $(40-49 \%)$ and fat $(8-$ $22 \%)$ content. The experiment involved 3265 one-year-old sheat fish $\left(\mathrm{Su}_{1}\right)$ of 209 and 295 g average individual weight (in 1996 and 1997, respectively). Analysed were 56 fish of 15 months (1997) and 17 months (1996) of age, individual weight 1288 and $752 \mathrm{~g}$ (1996 and 1997. respectively). The average values of blood indicators in fish of all the studied groups were the following: PCV $0.26 \mathrm{l} \cdot \mathrm{l}^{-1}$, Hb $56.88 \mathrm{~g} \cdot \mathrm{l}^{-1}, \mathrm{BC} 0.78 \mathrm{~T} \cdot \mathrm{l}^{-1}$, Leuko $30.13 \mathrm{G} \cdot \mathrm{l}^{-1}, \mathrm{MCV} 317.65 \mathrm{fl}, \mathrm{MCH}$ $68.90 \mathrm{pg}$ and $\mathrm{MCHC} 0.21 \mathrm{l} \cdot \mathrm{l}^{-1}$. The leukogram had a lymphocytic character with a lower number of mature granulocytes. Average values of the biochemical blood plasma indicators were as follows: glucose $4.96 \mathrm{mmol} \cdot \mathrm{l}^{-1}$. total protein (TP) $29.89 \mathrm{~g} \cdot \mathrm{l}^{-1}$, total lipids (TL) $8.81 \mathrm{~g} \cdot \mathrm{l}^{-1}$ and cholesterol (chol) $4.57 \mathrm{mmol} \cdot \mathrm{l}^{-1}$.

Significant changes $(P<0.05)$ in hematological indicators were found in fish fed the PD2 feed mixture and very significant $(P<0.01)$ differences in the Chol a TL values in fish fed BioMar and IV 97. These data characterise the adaptation reaction of the internal environment of wels to conditions of intensive aquaculture with warmed water and the nutritional value of used feeds.
\end{abstract}

Intensive aquaculture, Silurus glanis, wels, pelleted feed, blood indicators,

A good adaptability of wels (Silurus glanis L.) to various ecological, food and technological conditions enables its farming diversity in various production systems. Besides pond and combined culture, the whole wels production cycle from fry to marketable fish can be run in special facilities with controlled water temperature regime and utilizing commercial feeds (Jirásek et al. 1998).

The aim of the experiments performed in 1996 and 1997 was to test the production of twoyear-old wels of lower individual body mass in intensive aquaculture. The achieved production results are presented in the study of Jirásek and Mareš (1998).

\section{Materials and Methods}

The experiments were carried out in the fish farm Tisová (České rýbářstvi Mariánské Lázně P/C). Heated powerplant effluents were used. Water temperature was controlled using the water from the Ohre river. Partly shaded concretc raceways (production volume $3 \mathrm{~m}^{3}$, inflow rate $21 \cdot \mathrm{s}^{-1}$ ) were utilized for the experiments. The production and physiological effects of 4 imported pelleted feed produced by ALMA and BioMar. one domestic pelleted feed PD 2 and 3 experimental diets of own prescriptions (indicated A, B and W97) were tested in two replicates. The feeds differred in protein $(40-46 \%)$ and lipid content $(8-22 \%)$. All feeds were produced by extrusion.

\footnotetext{
Address for correspondence:

Prof. Ing. Jiři Jirásek. DrSc.

Department of Fisheries and Hydrobiology

Mendel University of Agriculture and Forestry

Zemědélska 1.61300 Brno. Czech Repuhlic

Phone : $+4205+5133268$

Fax: + +2054521 2044

E-mail: mares
} 
The duration of the experiment was 181 d in 1996 (May 7 - November 5) and 99 days ( June 16 - September 19) in 1997. The average initial body mass of one-year-old fish was 209 and $295 \mathrm{~g}$ in 1996 and 1997. respectively. Stock densities in raceways corresponded to 67 and 69 individuals per $\mathrm{m}^{-3}$, respectively.

Table 1

Hydrochemical indices of the system

\begin{tabular}{|c|c|}
\hline $\begin{array}{l}\text { Dissolved oxygen } \\
\left(\mathrm{mg} \cdot \mathrm{l}^{-1}\right)\end{array}$ & 7.71 \\
\hline $\begin{array}{l}\text { Oxygen saturation } \\
(\%)\end{array}$ & 80.50 \\
\hline $\mathrm{pH}$ & 7.68 \\
\hline $\begin{array}{l}\text { Alkalinity } \\
\left(\mathrm{mmol} \cdot \mathrm{l}^{-1}\right)\end{array}$ & 1.92 \\
\hline $\begin{array}{l}\text { Hardness of water } \\
\left(\mathrm{mmol} \cdot \mathrm{l}^{-1}\right)\end{array}$ & 3.42 \\
\hline $\begin{array}{l}\text { Chemical oxygen demand (Kubel) } \\
\left(\mathrm{mg} \cdot \mathrm{l}^{-1}\right)\end{array}$ & 5.99 \\
\hline $\begin{array}{l}\mathrm{NH}_{4}-\mathrm{N} \\
\left(\mathrm{mg} \cdot 1^{-1}\right)\end{array}$ & 1.65 \\
\hline $\begin{array}{l}\mathrm{NO}_{3}-\mathrm{N} \\
\left(\mathrm{mg} \cdot \mathrm{l}^{-1}\right)\end{array}$ & 7.77 \\
\hline $\begin{array}{l}\mathrm{NO}_{2}-\mathrm{N} \\
\left(\mathrm{mg} \cdot 1^{-1}\right)\end{array}$ & 0.07 \\
\hline $\begin{array}{l}\text { N organic } \\
\left(\mathrm{mg} \cdot 1^{-1}\right)\end{array}$ & 0.98 \\
\hline $\begin{array}{l}\mathrm{PO}_{4}{ }^{3} \mathrm{P} \\
\left(\mathrm{mg} \cdot \mathrm{l}^{-1}\right)\end{array}$ & 0.16 \\
\hline $\begin{array}{l}\text { P total } \\
\left(\mathrm{mg} \cdot 1^{-1}\right)\end{array}$ & 0.30 \\
\hline $\begin{array}{l}\mathrm{Ca} \\
\left(\mathrm{mg} \cdot 1^{-1}\right)\end{array}$ & 59.11 \\
\hline
\end{tabular}

Water quality in farming raceways was characterised by average values of basic hydrochemical indices (Table 1). Mean water temperature for the whole period of culture was to $22.1^{\circ} \mathrm{C}$ and $20.2{ }^{\circ} \mathrm{C}$ in 1996 and 1997 , respectively. The values of other hydrochemical indicators assessed in discharge water characterize the environmental conditions suitable for intensive wels culture.

After the experiments were finished, blood samples were collected by heart puncture (Jirásek et al. 1980) from 7 fish belonging to each of the 8 groups fed the experimental diets. The blood sampes were processed using the procedures described in the methodology of fish haematological investigations ( $S$ vobodova et al. 1986). The blood cell count (RBC), haematocrit (PCV), haemoglobin ( $\mathrm{Hb})$, mean corpuscular haemoglobin concentration (MCHC), mean corpuscular volume (MCV) and mean corpuscular hemoglobin $(\mathrm{MCH})$ were evaluated. Biochemical indices of blood plasma - total protein (TP), total lipids (TL), glucose (Glucose) and cholesterol (Chol). In differential leukocyte count. the lymphocytes, monocytes, blasts (myeloblasts, monoblasts, lymphoblasts) and cells of myeloid area (promyelocytes, neutrophilic myelocytes, neutrophilic metamyelocytes) and neutrophilic granulocytes with band or segmented nucleus.

The data were statistically evaluated. For the assessment of the significance of differences between individual feeding in each year, ANOVA with subsequent testing by Scheffe's method was utilized. The results are presented in the tables. The results are presented as mean and standard deviation $( \pm S D)$, and variation coefficient $(V)$.

\section{Results and Discussion}

With respect to the fact that all fish were raised under comparable environmental conditions, the differences are related above all to different quality of the diets.

Length-body mass characteristics of analyzed fish from individual experimental variants 
is presented in Table 2. Wels of total length (TL) $422-545 \mathrm{~mm}$, weight (W) $200-1015 \mathrm{~g}$ at the age of 16-17 months were used for the analyses.

Table 2

Length-weight characteristics of analysed wels

\begin{tabular}{|l|c|c|c|}
\hline Variable & $\begin{array}{c}\text { TL }(\mathrm{mm}) \\
\text { mean } \pm \text { SD }\end{array}$ & $\begin{array}{c}\text { SL }(\mathrm{mm}) \\
\text { mean } \pm \text { SD }\end{array}$ & $\begin{array}{c}\text { W }(\mathrm{g}) \\
\text { mean } \pm \text { SD }\end{array}$ \\
\hline 5.11 .1996 & & & \\
\hline Alma 6020 & $557.0 \pm 10.41$ & $529.0 \pm 15.60$ & $1.360 .7 \pm 126.9$ \\
\hline PD 2 & $550.7 \pm 14.84$ & $519.7 \pm 9.18$ & $1,197.8 \pm 174.7$ \\
\hline A & $558.2 \pm 17.67$ & $524.2 \pm 19.93$ & $1,166.8 \pm 69.57$ \\
\hline B & $573.2 \pm 25.54$ & $539.0 \pm 24.51$ & $1,424.8 \pm 194.2$ \\
\hline 19.9.1997 & & & \\
\hline Biomar 17 & $482.9 \pm 25.02$ & $446.3 \pm 22.24$ & $764.0 \pm 115.2$ \\
\hline Alma 6415 & $471.7 \pm 32.15$ & $430.1 \pm 30.05$ & $756.4 \pm 110.5$ \\
\hline Alma 6440 & $473.4 \pm 24.52$ & $435.0 \pm 23.95$ & $735.6 \pm 141.4$ \\
\hline W 97 & $496.1 \pm 24.39$ & $454.3 \pm 21.88$ & $753.1 \pm 94.76$ \\
\hline
\end{tabular}

The values of haematological and biochemical determinants found in wels in 1996 and 1997 are presented in Tables 3 and 5. Wels haemogram from an intensive aquaculture is characterized by the values found in individual parameters:

Haematocrit value (PCV)

In the set of analyzed fish in all experimental treatments, the mean value amounted to $0.261 \cdot 1^{-1}\left(0.21-0.301 \cdot \cdot^{-1}\right)$. In fish sampled in 1997 , the mean value was higher by $26 \%\left(0.291 \cdot \mathrm{l}^{-1}\right)$.

Haemoglobin ( $\mathrm{Hb})$

The mean amount of haemoglobin in the wels blood was $56.88 \mathrm{~g} \cdot \mathrm{l}^{-1}\left(48.71-66.30 \mathrm{~g} \cdot \mathrm{l}^{-1}\right)$. The stimulating effect of diets applied in 1997 was manifested by the increase of Hb values by $18 \%\left(61.60 \mathrm{~g} \cdot \mathrm{l}^{-1}\right)$ on average.

\section{Erythrocyte counts}

The mean number of erythrocytes $0.78 \mathrm{~T} \cdot \mathrm{I}^{-1}\left(0.65-0.88 \mathrm{~T} \cdot \mathrm{l}^{-1}\right)$ was found in the blood of all analyzed wels. A decline in erythrocyte counts $\left(0.65 \mathrm{~T} \cdot \mathrm{l}^{-1}\right)$ was found in fish pelleted feed PD 2.

The mean corpuscular volume (MCV), mean corpuscular haemoglobin $(\mathrm{MCH})$ and mean corpuscular haemoglobin concentration (MCHC) were assessed from basic values of the erythrocytes - they amounted to $317.65 \mathrm{fl}(272.68-407.66 \mathrm{fl}), 68.90 \mathrm{pg}(57.89-86.09 \mathrm{pg})$ and $0.211 \cdot \mathrm{l}^{-1}\left(0.21-0.23 \mathrm{l} \cdot \mathrm{l}^{-1}\right)$ on average, respectively. Significant difference $(\mathrm{P}<0.05)$ was found in the MCV and MCHC values in fish fed the diet PD 2.

The mean leukocyte count in wels blood amounted to $30.13 \mathrm{G} \cdot \mathrm{l}^{-1}\left(22.86-44.41 \mathrm{G} \cdot \mathrm{l}^{-1}\right)$. The highest count was found in wels fed the diet PD $2\left(44.41 \mathrm{G} \cdot \cdot^{-1}\right)$.

The results of differential leukocyte counts of wels are presented in Table 5. The percentual superiority of lymphocytes $(89.74 \%)$ is obvious from the data, the remaining percentage is presented by blasts $(2.74 \%)$, monocytes $(2.11 \%)$, promyelocytes $(0.88 \%)$, neutrophilic myelocytes $(2.43 \%)$ and neutrophilic metamyelocytes $(1.20 \%)$. Only $0.40 \%$ of band neutrophils and $0.20 \%$ segmented neutrophils present.

Differential leukocyte count has lymphocytic characteristics with lower proportion of mature granulocytes (bands and segmentes). This can be considered as a species-specific feature rather than a manifestation of any immunodeficiency or stress which can be manifested by drifting out of younger developmental stages of myelocytic cells. 
Table 3

Haematological indices of wels

\begin{tabular}{|c|c|c|c|c|c|c|c|c|c|}
\hline \multirow{2}{*}{\begin{tabular}{|l|} 
Feed \\
\end{tabular}} & & \multicolumn{4}{|c|}{1996} & \multicolumn{4}{|c|}{1997} \\
\hline & & Alma & PD 2 & A & B & Biomar & Alma & Alma & W97 \\
\hline \multicolumn{2}{|c|}{ Protein/Fat } & $49 / 14$ & $43 / 8$ & $40 / 10$ & $44 / 10$ & $42 / 22$ & $42.5 / 10$ & $45 / 12$ & $46 / 15$ \\
\hline \multirow{3}{*}{$\begin{array}{l}\text { PCV } \\
\left(1.1^{-1}\right)\end{array}$} & mean & 0.24 & 0.23 & 0.21 & 0.24 & 0.29 & 0.30 & 0.30 & 0.28 \\
\hline & $\mathrm{SD}$ & 0.05 & 0.07 & 0.05 & 0.05 & 0.03 & 0.02 & 0.03 & 0.03 \\
\hline & $\mathrm{V}(\%)$ & 21.28 & 28.82 & 24.53 & 19.57 & 9.55 & 5.52 & 8.39 & 9.33 \\
\hline \multirow{3}{*}{$\begin{array}{l}\mathbf{H b} \\
\left(\mathrm{g} . \mathrm{l}^{-1}\right)\end{array}$} & mean & 53.83 & 55.65 & 48.71 & 50.42 & 63.59 & 62.21 & 66.30 & 54.31 \\
\hline & SD & 11.44 & 5.56 & 15.25 & 11.16 & 5.94 & 4.36 & 6.66 & 24.15 \\
\hline & $\mathrm{V}(\%)$ & 21.25 & 9.99 & 31.30 & 22.14 & 9.34 & 7.01 & 10.04 & 44.47 \\
\hline \multirow{3}{*}{$\begin{array}{l}\text { Ery } \\
\left(\mathrm{T} .1^{-1}\right)\end{array}$} & mean & 0.80 & 0.65 & 0.79 & 0.88 & & & & \\
\hline & SD & 0.24 & (0.03 & 0.14 & 0.14 & & & & \\
\hline & $\mathrm{V}(\%)$ & 29.73 & 5.28 & 17.66 & 16.31 & & & & \\
\hline \multirow{3}{*}{$\begin{array}{l}\text { MCV } \\
\text { (fl) }\end{array}$} & mean & $310.5^{\mathrm{ab}}$ & $107.7^{b}$ & $297.8^{a}$ & $272.7^{\mathrm{a}}$ & & & & \\
\hline & SD & 94.74 & 36.60 & 35.38 & 49.89 & & & & \\
\hline & $\mathrm{V}(\%)$ & 30.51 & 8.98 & 12.64 & 18.27 & & & & \\
\hline \multirow{3}{*}{$\begin{array}{l}\mathbf{M C H} \\
(\mathrm{pg})\end{array}$} & mean & 70.72 & 86.09 & 60.91 & 57.89 & & & & \\
\hline & SD & 21.10 & 9.67 & 10.93 & 13.52 & & & & \\
\hline & $\mathrm{V}(\%)$ & 29.83 & 11.23 & 17.94 & 23.35 & & & & \\
\hline \multirow{3}{*}{$\begin{array}{l}\text { MCHC } \\
\left(\mathrm{L} . \mathrm{l}^{-1}\right)\end{array}$} & mean & $0.23^{\mathrm{ab}}$ & $0.22^{\mathrm{b}}$ & $0.21^{\mathrm{ab}}$ & $0.21^{\mathrm{a}}$ & 0.22 & 0.21 & 0.22 & 0.19 \\
\hline & SD & 0.01 & 0.01 & 0.02 & 0.02 & 0.02 & 0.01 & 0.01 & 0.08 \\
\hline & $\mathrm{V}(\%)$ & 5.65 & 4.36 & 7.86 & 8.17 & 7.20 & 2.77 & 4.65 & 43.74 \\
\hline \multirow{3}{*}{$\begin{array}{l}\text { Leuko } \\
\left(\mathrm{G} . \mathrm{l}^{-1}\right)\end{array}$} & mean & 31.78 & 44.41 & 31.54 & 34.95 & 24.65 & 23.15 & 27.70 & 22.86 \\
\hline & SD & 9.30 & 12.60 & 5.70 & 6.50 & 4.17 & 7.16 & 6.70 & 8.51 \\
\hline & $\mathrm{V}(\%)$ & 29.26 & 28.36 & 18.07 & 18.60 & 16.91 & 30.94 & 27.11 & 37.23 \\
\hline
\end{tabular}

No significant differences were found between the values which are indicated by the same letters. In case of their total absence in any of the examined parameters, the values are not indicated. Small letters and capitals are used for indicating the significance of differences at the level of $\mathrm{P}<0.05$ and $\mathrm{P}<0.01$, respectively.

The glucose concentration in blood plasma of analyzed fish oscillated around 4.69 $\mathrm{mmol} \cdot \mathrm{l}^{-1}\left(2.82-6.59 \mathrm{mmol} \cdot \mathrm{l}^{-1}\right)$. The values found in wels of all treatments in 1997 were almost twice as high $\left(6.35 \mathrm{mmol} \cdot \mathrm{l}^{-1}\right.$ as those in $1996\left(3.3 \mathrm{mmol} \cdot \mathrm{l}^{-1}\right)$.

The concentration of total protein in blood plasma of experimental fish was $29.89 \mathrm{~g} \cdot \mathrm{l}^{-1}$ $\left(26.88-35.52 \mathrm{~g} \cdot \mathrm{l}^{-1}\right)$. The highest protein concentration $\left(35.52 \mathrm{~g} \cdot \mathrm{l}^{-1}\right)$ was assessed in the plasma of fish fed ALMA mixture for wels (6 415).

The average concentration of total lipids (TL) in plasma amounted to $28.81 \mathrm{~g} \cdot \mathrm{l}^{-1}(26.88$ $\left.35.52 \mathrm{~g} \cdot \mathrm{l}^{-1}\right)$ and cholesterol concentration (Chol) $4.57 \mathrm{mmol} \cdot \mathrm{l}^{-1}\left(2.20-7.84 \mathrm{mmol} \cdot \mathrm{l}^{-1}\right)$. Higher lipid content in feeds fed in 1997 enhanced the TL value in comparison with previous year by $75 \%$ and cholesterol level in the plasma by $55 \%$.

The values of haematological and biochemical indices of blood plasma of wels aged 11 and 16 months and individual body mass 340 - $725 \mathrm{~g}$ from various culture conditions are presented by Mareš et al. (1993). In comparison with the data of these authors, approximately by one half lower number of erythrocytes was found in the blood of wels from intensive culture at Tisová at comparable concentration of haemoglobin and hematocrit level. This was due to their larger volume and higher amount of haemoglobin per erythrocyte. Leukocyte count was lower (approximately by $35 \%$ ) as compared to the results of the above mentioned authors. 
Table 4

Differential leukocyte count of wels

\begin{tabular}{|c|c|c|c|c|c|c|c|c|c|}
\hline \multirow{2}{*}{\begin{tabular}{|l} 
Feed \\
\end{tabular}} & & \multicolumn{4}{|c|}{1996} & \multicolumn{4}{|c|}{1997} \\
\hline & & Alma & PD 2 & A & B & Biomar & Alma & Alma & W97 \\
\hline \multicolumn{2}{|l|}{ Protein/Fat } & $49 / 14$ & $43 / 8$ & $40 / 10$ & $44 / 10$ & $42 / 22$ & $42.5 / 10$ & $45 / 12$ & $46 / 15$ \\
\hline \multirow{3}{*}{$\begin{array}{l}\text { Blasts } \\
(\%)\end{array}$} & mean & $1.29^{\mathrm{a}}$ & $2.14^{\mathrm{ab}}$ & $3.14^{\mathrm{ab}}$ & $4.86^{b}$ & 2.57 & 3.14 & 2.57 & 2.14 \\
\hline & SD & 1.60 & 1.22 & 2.61 & 2.55 & 1.72 & 1.21 & 1.40 & 1.57 \\
\hline & $\mathrm{V}(\%)$ & 122.72 & 56.70 & 83.03 & 52.39 & 66.82 & 38.66 & 54.34 & 73.43 \\
\hline \multicolumn{2}{|c|}{ Monocytes mean } & 2.57 & 1.14 & 2.71 & 0.86 & 3.00 & 2.86 & 1.71 & 2.00 \\
\hline \multirow[t]{2}{*}{$(\%)$} & SD & 1.81 & 0.90 & 1.80 & 1.21 & 1.63 & 1.22 & 1.25 & 1.63 \\
\hline & $\mathrm{V}(\%)$ & 70.49 & 78.73 & 66.30 & 141.75 & 54.43 & 42.52 & 73.12 & 81.65 \\
\hline \multirow{3}{*}{$\begin{array}{l}\text { Promyelo } \\
(\%)\end{array}$} & mean & $0.29^{a}$ & $1.00^{\mathrm{ab}}$ & $2.00^{b}$ & $1.71^{\mathrm{ab}}$ & 1.29 & 0.29 & 0.29 & 0.14 \\
\hline & $\mathrm{SD}$ & 0.49 & 1.00 & 1.29 & 1.25 & 1.80 & 0.49 & 0.76 & 0.38 \\
\hline & $\mathrm{V}(\%)$ & 170.78 & 100.00 & 64.55 & 73.12 & 139.96 & 170.78 & 264.58 & 264.58 \\
\hline \multirow{3}{*}{$\begin{array}{l}\text { N.myelo } \\
(\%)\end{array}$} & mean & 2.14 & 3.43 & 1.29 & 3.00 & 1.43 & 2.00 & 2.00 & 4.14 \\
\hline & SD & 2.41 & 5.13 & 1.38 & 1.53 & 0.98 & 1.63 & 1.00 & 1.07 \\
\hline & $\mathrm{V}(\%)$ & 112.48 & 149.54 & 107.34 & 50.92 & 68.31 & 81.65 & 50.00 & 25.80 \\
\hline \multirow{3}{*}{$\begin{array}{l}\text { N.metamy } \\
(\%)\end{array}$} & mean & 0.57 & 1.86 & 0.71 & 0.69 & 1.43 & 1.29 & 1.14 & 1.71 \\
\hline & $\mathrm{SD}$ & 0.53 & 3.29 & 1.11 & 0.69 & 1.27 & 1.11 & 1.77 & 2.06 \\
\hline & $\mathrm{V}(\%)$ & 93.54 & 177.04 & 155.78 & 80.51 & 89.07 & 86.54 & 155.12 & 120.09 \\
\hline \multirow{3}{*}{$\begin{array}{l}\text { Bands } \\
(\%)\end{array}$} & mean & 1.00 & 1.14 & 0.00 & 0.00 & 0.57 & 0.14 & 0.29 & 0.00 \\
\hline & $\mathrm{SD}$ & 0.82 & 2.19 & 0.00 & 0.00 & 0.53 & 0.38 & 0.49 & 0.00 \\
\hline & $\mathrm{V}(\%)$ & 81.65 & 191.89 & 0.00 & 0.00 & 93.54 & 264.58 & 170.78 & 0.00 \\
\hline \multirow{3}{*}{$\begin{array}{l}\text { Segments } \\
(\%)\end{array}$} & mean & 0.14 & 0.14 & 0.00 & 0.00 & 0.71 & 0.29 & 0.00 & 0.14 \\
\hline & $\mathrm{SD}$ & 0.38 & 0.38 & 0.00 & 0.00 & 0.76 & 0.76 & 0.00 & 0.38 \\
\hline & $\mathrm{V}(\%)$ & 264.58 & 264.58 & 0.00 & 0.00 & 105.83 & 264.58 & 0.00 & 264.58 \\
\hline \multicolumn{2}{|c|}{ Lymphocyte mean } & 89.14 & 89.14 & 90.14 & 88.71 & 89.00 & 90.00 & 92.00 & 89.71 \\
\hline \multirow[t]{2}{*}{$(\%)$} & $\mathrm{SD}$ & 7.93 & 11.88 & 4.71 & 4.50 & 3.27 & 4.08 & 2.45 & 4.07 \\
\hline & $\mathrm{V}(\%)$ & 8.89 & 13.33 & 5.22 & 5.07 & 3.67 & 4.54 & 2.66 & 4.54 \\
\hline
\end{tabular}

The achieved data about wels haematological indices are remarkably coincident with the value range presented for carp (Svobodová et al. 1986), except for the lower haemoglobin concentration. Lower erythrocyte counts are closer to values presented for rainbow trout.

It is obvious that the values of wels blood indices reflect the conditions of farming environment whereas the values of biochemical parameters of blood plasma were more influenced by nutrition (quality of diets). The favourable effect upon the values of haematological parameters was evident in fish fed nutritionally balanced imported feeds. High lipid content in the feed was manifested by increased concentration of total lipids and cholesterol in blood plasma.

With respect to the fact that the physiological state of wels farmed under conditions of intensive aquaculture with heated water was good and fish were not subjected to any stress, the indicators of their internal environment can be considered as physiological for intensive production system of culture and utilized level of nutrition. 
Table 5

Biochemical indices of wels

\begin{tabular}{|c|c|c|c|c|c|c|c|c|c|}
\hline \multirow{2}{*}{\multicolumn{2}{|c|}{ Feed }} & \multicolumn{4}{|c|}{1996} & \multicolumn{4}{|c|}{1997} \\
\hline & & Alma & $\mathrm{PD} 2$ & $\mathrm{~A}$ & B & Biomar & Alma & Alma & W97 \\
\hline \multicolumn{2}{|l|}{ Protein/Fat } & $49 / 14$ & $43 / 8$ & $40 / 10$ & $44 / 10$ & $+2 / 22$ & $42.5 / 10$ & $45 / 12$ & $46 / 15$ \\
\hline \multirow{3}{*}{$\begin{array}{l}\text { Glucose } \\
\left(\mathrm{mmol} . \mathrm{I}^{-1}\right)\end{array}$} & mean & 3.14 & 2.91 & 2.82 & 3.27 & 6.16 & 6.59 & 6.31 & 6.35 \\
\hline & SD & 0.54 & 0.62 & 0.61 & 0.68 & 1.26 & 1.00 & 1.69 & 2.01 \\
\hline & $\mathrm{V}(\%)$ & 17.28 & 21.21 & 21.54 & 20.80 & 20.43 & 15.25 & 26.87 & 31.68 \\
\hline \multirow{3}{*}{$\begin{array}{l}\text { TP } \\
\left(\mathrm{g} . \mathrm{l}^{-1}\right)\end{array}$} & mean & 29.14 & 26.88 & 27.08 & 31.39 & 31.25 & 35.52 & 29.01 & 28.85 \\
\hline & $\mathrm{SD}$ & 6.18 & 5.63 & 7.43 & 7.68 & 2.33 & 3.58 & 13.15 & 3.61 \\
\hline & $V(\%)$ & 21.20 & 20.96 & 27.42 & 24.64 & 7.45 & 10.08 & 45.34 & 12.53 \\
\hline \multirow{3}{*}{$\begin{array}{l}\text { Chol } \\
\left(\mathrm{mmol.} \mathrm{I}^{-1}\right)\end{array}$} & mean & $7.22^{\mathrm{B}}$ & $2.20^{\mathrm{A}}$ & $2.32^{\mathrm{A}}$ & $2.63^{\mathrm{A}}$ & $7.84^{\mathrm{B}}$ & $5.87^{\mathrm{B}}$ & $6.02^{B}$ & $2.48^{\mathrm{A}}$ \\
\hline & $\mathrm{SD}$ & 2.16 & 0.72 & 0.53 & 0.70 & 2.57 & 0.73 & 0.81 & 0.48 \\
\hline & $V(\%)$ & 29.97 & 32.81 & 22.64 & 26.58 & 32.83 & 12.40 & 13.53 & 19.24 \\
\hline \multirow{3}{*}{$\begin{array}{l}\text { TL } \\
\left(\mathrm{g} .1^{-1}\right)\end{array}$} & mean & 11.26 & 3.87 & 5.49 & 5.03 & $15.19^{B}$ & $12.09^{A B}$ & $11.27^{\mathrm{AB}}$ & $6.30^{\mathrm{A}}$ \\
\hline & $\mathrm{SD}$ & 5.18 & 1.23 & 1.63 & 1.28 & 5.06 & 2.16 & 1.68 & 1.07 \\
\hline & $\mathrm{V}(\%)$ & 46.02 & 31.81 & 29.73 & 25.41 & 33.31 & 17.88 & 14.95 & 16.94 \\
\hline
\end{tabular}

\section{Hematologické a biochemické parametry krve sumce velkého (Silurus glanis L.) z intenzivní akvakultury}

Cílem studie bylo stanovení hodnot základních ukazatelů krve a biochemických ukazatelů krevní plazmy sumce velkého (Silurus glanis L.) z intenzivního chovu na oteplené elektrárenské vodě při absenci přirozené potravy. Studie zahrnovala 8 krmných pokusů, ve kterých byly použity 4 importované (ALMA, BioMar) a 4 tuzemsky vyrobené granulované krmné směsi s diferencovaným obsahem proteinu (40 - $49 \%)$ a tuku $(8-22 \%)$. K pokusům byl použit roček $\left(\mathrm{Su}_{1}\right)$ sumce o průměrné individuální hmotnosti 209 g (1996) a 295 g (1997) v celkovém počtu 3265 kusů. Analýzy byly provedeny u 56 kusů ryb ve věku 15 měsíců (1997), resp. 17 měsíců (1996), při individuální hmotnosti 1288 g (1996) a 752 g (1997). U ryb všech sledovaných skupin byly zjišsěny tyto průměrné hodnoty ukazatelů krve: PCV $0,26 \mathrm{l} \cdot \mathrm{l}^{-1}$, Hb 56,88 $\mathrm{g} \cdot \mathrm{l}^{-1}$, RBC 0,78 $\mathrm{T} \cdot \mathrm{l}^{-1}$, Leuko 30,13 $\mathrm{G} \cdot \mathrm{l}^{-1}, \mathrm{MCV} 317,65 \mathrm{fl}, \mathrm{MCH}$ $68,90 \mathrm{pg}$ a MCHC $0,21 \mathrm{l} \cdot \mathrm{1}^{-1}$. Leukogram se vyznačoval lymfocytárním charakterem s nižším zastoupením zralých granulocytů. Sledované biochemické ukazatele krevní plazmy vykazovaly tyto průměrné hodnoty: Gluk 4,96 $\mathrm{mmol} \cdot \mathrm{l}^{-1}$, TP $29,89 \mathrm{~g} \cdot \mathrm{l}^{-1}$, Tl $8,81 \mathrm{~g} \cdot \mathrm{l}^{-1}$ a Chol 4,57 $\mathrm{mmol} \cdot \mathrm{l}^{-1}$.

Významné změny $(\mathrm{P}<0,05)$ hematologických ukazatelů byly zjištěny u ryb skupiny krmené směsí $\mathrm{PD} 2$ a velmi významné $(\mathrm{P}<0,01)$ rozdíly hodnot Chol a TL u ryb skupiny BioMar a W 97. Zjištěné údaje charakterizují adaptační reakce vnitřního prostředí sumce na podmínky prostředí intenzivní akvakultury s oteplenou vodou a nutriční hodnotu použitých krmiv.

\section{Acknowledgement}

This study was supported by the grant project NAZV IE 5139, and performed at the Department of Fisheries and Hydrobiology MZLU Brno in 1995-1997. 


\section{References}

JIRÁSEK, J., PRAVDA, D., HAMPL, A. 1980: An effective method of blood sampling for large scale hematological investigations of fish fry (Efektivní metoda odběru krve pro hromadná hematologická šetření rybího plůdku). Acta Univ.Agricult., fac. Agronom. Brno 28: 175-182

JIRÁSEK, J., PENÁZZ, M., HAMÁĆKOVÁ, J. 1998: Biological and technological aspects of wels (Silurus glanis L.) culture under conditions of the Czech Republic (Biologické a technologické aspekty chovu sumce velkého (Silurus glanis L.) v podmínkách CR). Project report NAZV IE 5139, MZLU v Brnè, 49 p.

JIRÁSEK, J., MAREŠ, J. 1998: Intensive culture of wels in a facility with heated water (Intenzivni chov sumce velkého v zařizení s oteplenou vodou). Sbor. Referátů z III. české ichtyologické konference, Vodňany 6.-7. května 1998: 223-228

MAREŚ, J., PALÁĆKOVÁ, J., JIRÁSEK, J., PRAVDA, D. 1993: A contribution to studies on the hematology of sheat-fish (Silurus glanis L.). Proceedings of the $3^{\text {rd }}$ Ichtyohaematological Conference, Litomyšl, Czech Rep., November 30 - December 2 1993: 79-82

SVOBODOVÁ, Z., PRAVDA, D., PALÁĆKOVÁ, J. 1986: Unified methods of fish hematological investigations (Jednotné metody hematologického vyšetřování ryb). Edice Metodik, VÚRH Vodňany, č. 22, 36 p. 